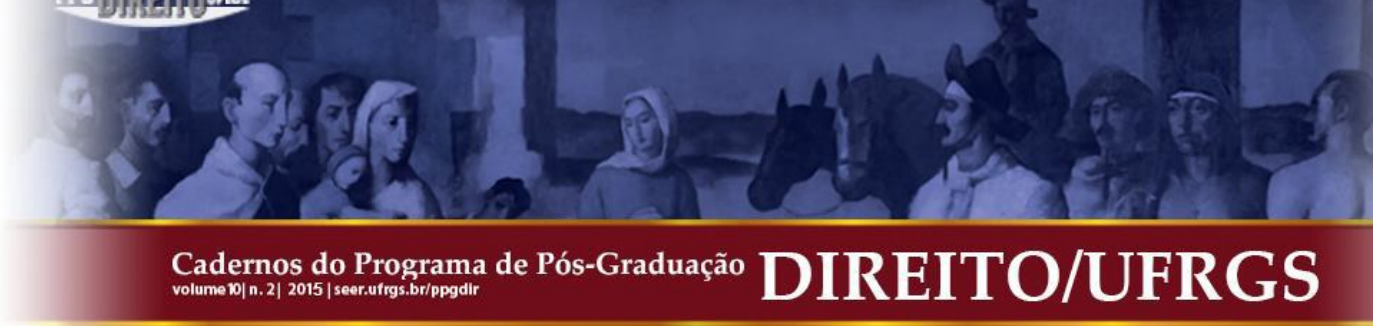

\title{
INCENTIVOS FISCAIS E SUAS CONDIÇÕES DE VALIDADE: IGUALDADE E PROPORCIONALIDADE
}

\author{
TAX INCENTIVES AND ITS VALIDITY CONDITIONS: EQUALITY AND \\ PROPORTIONALITY
}

\begin{abstract}
Alan Luiz Bonat*
André Folloni**

RESUMO: Este artigo tem como objetivo analisar a promoção de direitos fundamentais como parâmetros para a concessão de incentivos fiscais. Para tanto, em um primeiro momento, para justificar a abordagem heterodoxa que será utilizada, o artigo tece considerações sobre a possibilidade de ciência normativa no Direito Tributário, em oposição às determinações metodológicas hegemônicas, fixando assim seu método. Sob o pressuposto de que, em lugar de competição ou oposição, é necessária colaboração entre o Estado e os particulares para a promoção do desenvolvimento nacional, e compreendendo os incentivos fiscais como um meio apto, em certos casos, para fomentar essa colaboração, o estudo investiga os problemas apresentados pelos benefícios fiscais diante da igualdade tributária e como a proporcionalidade pode ser eleita como a forma de avaliar a constitucionalidade dos incentivos fiscais considerando sua intrínseca potencialidade de restrição de direitos fundamentais.
\end{abstract}

PALAVRAS-CHAVE: Incentivos Fiscais. Igualdade tributária Proporcionalidade. Desenvolvimento nacional. Intervenção do Estado.

SUMÁRIO: Introdução. 1. Ciência Positiva e Ciência Normativa. 2. Incentivos Fiscais e Igualdade Tributária. 3. Incentivos Fiscais, Direitos Fundamentais e Proporcionalidade. Considerações finais. Referências.

\section{INTRODUÇÃO}

No capítulo relativo aos princípios gerais da atividade econômica, mais especificamente em seu artigo 174, a Constituição impõe ao Estado atuação como agente normativo e regulador daquelas atividades, incumbindo-lhe as funções de fiscalização, incentivo e planejamento, intervindo assim sobre a economia.

Um dos instrumentos de que o Estado dispõe para intervir sobre a economia na função de incentivo é a tributação. O poder público pode majorar tributos visando desestimular

\footnotetext{
* Mestrando em Direito Econômico e Desenvolvimento na Pontifícia Universidade Católica do Paraná (PUCPR).

** Professor do Programa de Pós-Graduação em Direito, Mestrado e Doutorado, da Pontifícia Universidade Católica do Paraná (PUC-PR).
} 


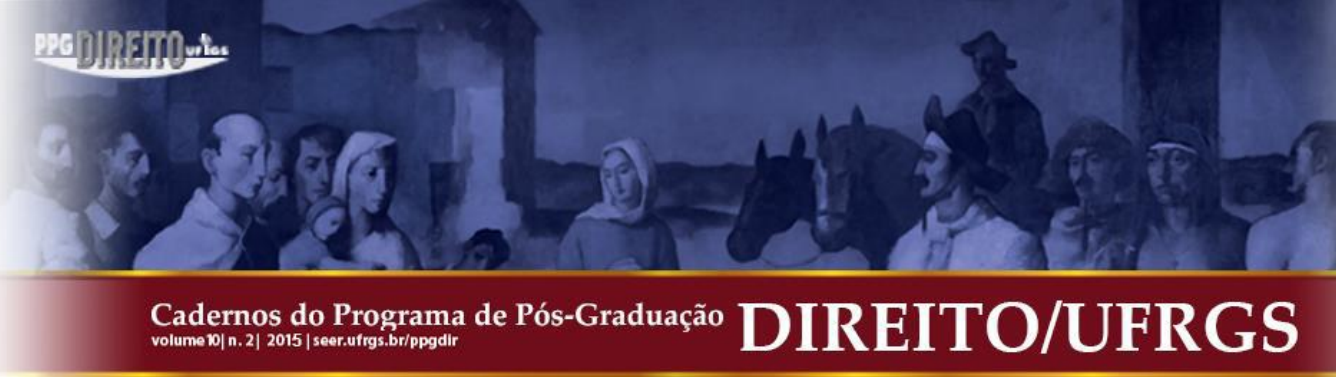

determinados comportamentos, ou induzir a adoção de determinadas condutas pelos agentes econômicos pela desoneração de suas atividades. No Brasil, frequentemente, talvez abusivamente, o Estado utiliza a concessão de incentivos fiscais para incentivar determinados setores da economia, inclusive ordinariamente, isto é, não apenas em momentos de crise.

Incentivos fiscais, por exemplo, são utilizados com o escopo de promover o desenvolvimento de determinada região do país, como na concessão de benefícios tributários para sociedades empresárias que vierem a se estabelecer na Zona Franca de Manaus, com o propósito de tornar aquela região um centro comercial, industrial, nos termos do art. $1 .^{\circ}$ do Decreto-Lei n. 288/1967. Outra possibilidade concreta é o uso de tributos para promover direitos sociais, como a isenção do Imposto sobre Produtos Industrializados das sociedades empresárias fabricantes de equipamentos de informática destinados a escolas das redes públicas de ensino federal, estadual, distrital ou municipal, prevista na Lei n. 12.249/2010. E assim por diante.

Mas a concessão de incentivos fiscais é complexa. Apesar de se tratar de uma opção política cuja competência e legitimidade são atribuídas ao Poder Legislativo, tal escolha deve ser pautada por alguns critérios constitucionais, à medida que envolvem diretamente o preceito constitucional da igualdade tributária. Todo incentivo é, também, desigualdade: tributar menos alguma atividade para incentivá-la significa dar, a ela, um tratamento desigual em relação à atividade não incentivada.

Estudar incentivos fiscais em suas relações com a igualdade tributária é estudar a potencial afronta a um dos princípios estruturantes mais fundamentais do Direito Constitucional brasileiro. Por isso, o estudo acerca das delimitações da possibilidade de concessão de incentivos fiscais é importante para a comunidade jurídica e, em especial, para a Ciência do Direito Tributário.

Nesse contexto, o presente artigo examina a proporcionalidade como um exame necessário, embora não suficiente, para avaliar a validade da concessão de incentivos de natureza tributária.

Para tanto, inicialmente será delineada a perspectiva metodológica que orientará este trabalho, expondo-se o método tradicionalmente empregado na Ciência do Direito Tributário desenvolvida no Brasil, distinguindo-se as possibilidades de produção científica positiva e normativa e fazendo-se uma opção decidida. 


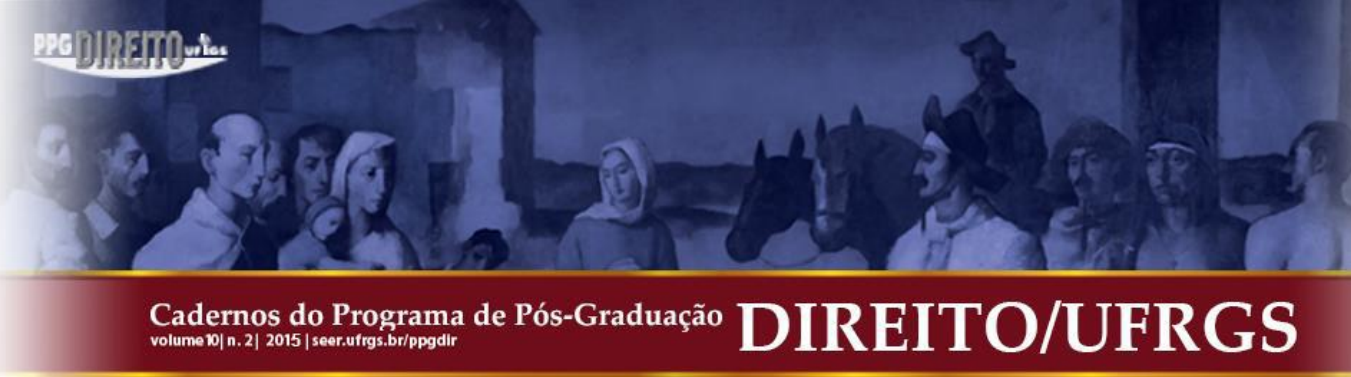

Em seguida, tendo como pano de fundo o objetivo fundamental de desenvolvimento nacional previsto no artigo $3 .^{\circ}$, II, da Constituição, e a possibilidade de utilização de incentivos fiscais com o intuito de promover a colaboração entre o Poder Público e particulares na consecução do referido objetivo, o estudo evidenciará o problema da concessão de incentivos fiscais em face da igualdade tributária, indicando a necessidade de serem observados critérios para a utilização dos referidos benefícios.

Então, ao final, o artigo pretende apresentar como a promoção dos direitos fundamentais pode ser um objetivo a ser buscado com a utilização dos incentivos fiscais, contribuindo com o desenvolvimento nacional, mas demandando o exame da proporcionalidade como uma etapa necessária da avaliação das condições de validade dos benefícios fiscais.

\section{CIÊNCIA POSITIVA E CIÊNCIA NORMATIVA}

Discorrendo acerca da história das ciências no Século XX, e mais especificamente a respeito da ciência econômica, W. Brian Arthur, um dos fundadores das Complexity Economics, cogita de qual teriam sido as características que definiriam uma atividade como científica nesse período. Conclui que a capacidade de predição, de previsão do comportamento futuro dos sistemas avaliados no presente, ao lado da clara distinção entre o sujeito e o objeto, estão entre as principais qualidades do conhecimento definido como científico. Contudo, já ao final do século passado, essas características começaram a se dissipar, perdendo força o pensamento positivista dominante. Doravante, poder prever o comportamento futuro de um sistema não mais é requisito de cientificidade do conhecimento produzido a respeito daquele sistema. ${ }^{1}$

De certo modo, pode-se dizer que tal transformação nas ciências vem chegando também à Ciência do Direito Tributário produzida no Brasil, ainda que timidamente. O paradigma tradicional adotado, e ainda predominante, é o positivismo jurídico kelseniano, expressamente adotado como vetor metodológico por setores expressivos do Direito Tributário no Brasil, principalmente desde o início da década de 1970. Conforme esses

\footnotetext{
1 ARTHUR, W. Brian. The end of certainty in economics. In: AERTS, Diederik; BROEKAERT, Jan; MATHIJS, Ernest (Eds.). Einstein meets Magritte: an interdisciplinary reflection on science, nature, art, human action and society. v. 1. Amsterdam: Springer, 1999, p. 255.
} 


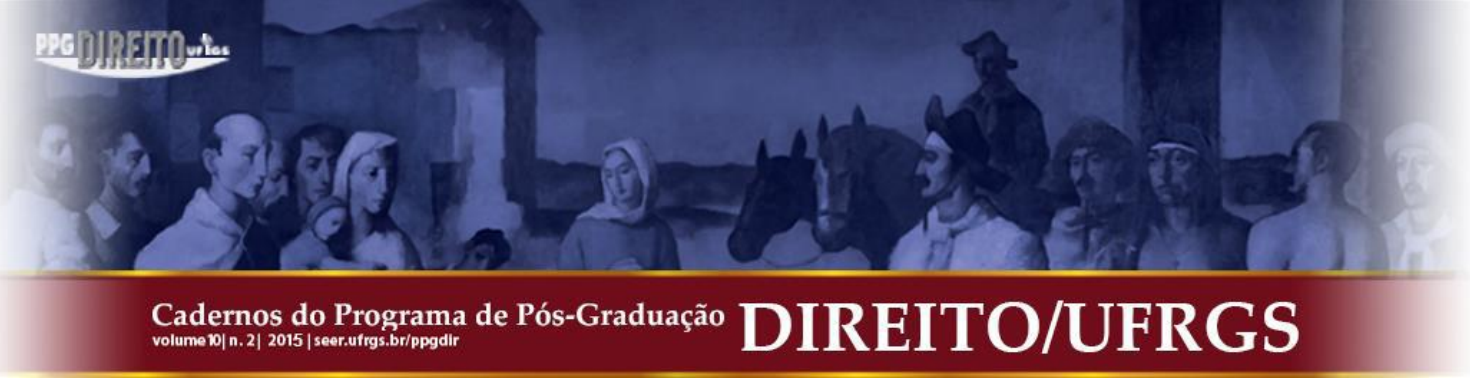

setores, o Direito Tributário adquire autonomia didática a partir de sua cientificidade, de que é condição a redução do seu objeto de estudo ao direito positivo existente, limitando-se o cientista à sua descrição neutra e imparcial, e reduzindo-o às normas jurídicas que dispõem sobre a instituição, fiscalização e arrecadação dos tributos. ${ }^{2}$ Assim, a Ciência do Direito Tributário desenvolvida no Brasil aprofundou o estudo do direito tributário a respeito das normas que cuidam da instituição, arrecadação ou fiscalização dos tributos, mas pouco se pesquisou além disso, sendo relativamente reduzida, por exemplo, a investigação dos efeitos gerados pelas normas tributárias no ambiente social no qual se inserem e nos sujeitos com os quais interagem. ${ }^{3}$

Apesar desse ainda ser o paradigma predominante na doutrina nacional, surgem propostas alternativas, algumas das quais se preocupando não somente com a explicação objetiva das normas jurídicas já existentes, mas também com a análise pragmática do Direito Tributário.

Como exemplo dessas propostas, deve-se referir José Souto Maior Borges. O autor, recentemente, tem proposto o estudo interdisciplinar do Direito Tributário e, sob o ponto de vista do objeto, com ênfase menos na norma de conduta do que na conduta normada, menos na sintaxe e semântica do que na pragmática normativa. Por isso, ressalta a necessidade de exame da função tributária, em substituição ao exame exclusivamente estrutural do Direito Tributário - aqui sob influência declarada de Norberto Bobbio. ${ }^{4}$

Outro exemplo que pode ser trazido é a doutrina de Marco Aurélio Greco. Esse autor tem salientado a importância de se reconhecer "a tributação como exercício de uma atividade no desempenho de uma função, pois isto implica deslocar a sociedade civil de mera destinatária e submetida ao poder formal, para assumir o papel de protagonista positiva do direcionamento a imprimir a esta função". 5 Nota-se, aqui, também a preocupação com o aspecto funcional da tributação e, por consequência, do Direito Tributário, o que demanda incremento teórico e metodológico.

\footnotetext{
${ }^{2}$ FOLLONI, André. Ciência do direito tributário no Brasil: crítica e perspectivas a partir de José Souto Maior Borges. São Paulo: Saraiva, 2013, p. 65; ÁVILA, Humberto. A doutrina e o Direito Tributário. In: ÁVILA, Humberto. (Org.). Fundamentos do Direito Tributário. Madri: Marcial Pons, 2012, p. 224.

${ }^{3}$ FOLLONI, André. Reflexões sobre complexity science no Direito Tributário. In: MACEI, Demetrius Nichele et al. (Org.). Direito tributário e filosofia. Curitiba: Instituto Memória, 2014, p. 25.

${ }^{4}$ BORGES, José Souto Maior. Um ensaio interdisciplinar em Direito Tributário: superação da dogmática. Revista Dialética de Direito Tributário, São Paulo, n. 211, abr./2013, p. 109; BOBBIO, Norberto. Da estrutura à função: novos estudos de teoria do direito. Barueri-SP: Manole, 2007.

${ }_{5}^{5}$ GRECO, Marco Aurélio. Do poder à função tributária. In: FERRAZ, Roberto. Princípios e limites da tributação 2. São Paulo: Quartier Latin, 2009, p. 176.
} 


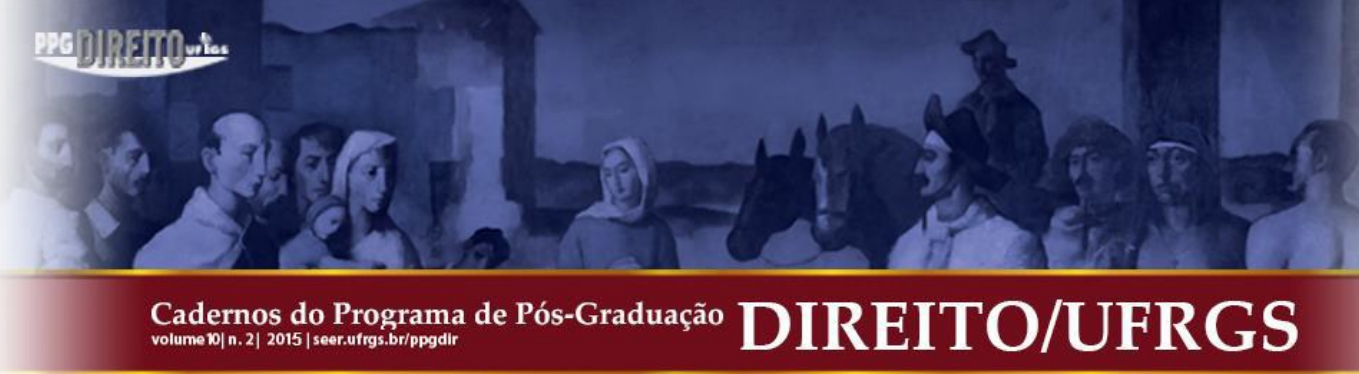

A busca pelo ideal científico anteriormente mencionado foi uma das causas que levou à redução da importância doutrinária. Essa é a opinião, por exemplo, de Humberto Ávila. Refletindo acerca do papel da comunidade científica no tocante à interpretação e aplicação do Direito, o autor leciona que, no passado, a doutrina desempenhava um papel importante, pois além de descrever e esclarecer o conteúdo das fontes normativas, colaborava com a inovação de tais fontes. Mas ao reduzir seu objeto de estudo à descrição do Direito posto, afastaram-se diversas outras funções da doutrina, como a indicação de qual alternativa interpretativa seria mais adequada ou a análise "dos princípios que protegem determinados bens jurídicos e que determinam a promoção de fins", resultando na perda da sua importância prática, de sua influência na atividade de criação de aplicação do Direito, seja pelo Poder Judiciário, seja pelos poderes políticos. ${ }^{6}$

Nesse contexto mais recente, a orientação da atividade de elaboração do Direito estaria excluída do escopo de estudo da Ciência do Direito, suprimindo dela uma das funções anteriormente mais importantes: a de ciência da elaboração da lei. É o que ensina Ruy Barbosa Nogueira, para quem o cientista do Direito, além do conhecimento a respeito da legislação, deve emitir juízos de valor, criticando os problemas da legislação existente e contribuindo para o aprimoramento legislativo. ${ }^{7}$ É dizer, deve atuar também no âmbito da normatividade, não apenas explicando como o Direito é, mas avançando para dizer como ele deve ser.

Em tal perspectiva, é possível atribuir à Ciência do Direito uma dupla função: positiva e normativa. Na primeira, o cientista centra seus estudos sobre o direito posto, orientando a aplicação das normas jurídicas existentes em um determinado caso concreto. Por outro lado, na função normativa, investiga o Direito existente, aponta suas imperfeições e sustenta como ele deveria ser para que fosse mais adequado. Em uma, trabalha com pretensão de dizer como as coisas são; em outra, labora com a pretensão de dizer como as coisas devem ser. Nesse segundo sentido, o cientista deve se esforçar para oferecer soluções para os problemas práticos apresentados. Inclusive no Direito Tributário:

No direito tributário, duas ordens de soluções devem ser distinguidas. Atuar na interpretação e na aplicação do direito a um caso concreto, com vistas a dar uma solução jurídica a um problema posto, é fazer uma ciência que se poderia denominar

\footnotetext{
${ }^{6}$ ÁVILA, Humberto. A doutrina e o Direito Tributário, op. cit., p. 225.

${ }^{7}$ NOGUEIRA, Ruy Barbosa. Curso de direito tributário. 14. ed., atual. São Paulo: Saraiva, 1995, p. 24.
} 
"positiva": procura, sabendo como o direito é, e como o caso fático é, dizer qual a solução correta. (...) Atuar na modificação do direito, por demonstrar a incorreção de determinadas fixações de ilicitudes ou ilicitudes, direitos e deveres, proibições, permissões e obrigações, é fazer uma ciência que pode ser chamada "normativa": diz que o direito, como é, é errado, e que deveria ser de outro modo. ${ }^{8}$

O presente artigo, admitindo essa dupla vertente, pretende analisar a concessão de incentivos fiscais em suas relações com a igualdade tributária, para verificar como se dá essa relação de tensão gerada pelo desigualamento de incidências tributárias, e avançar para dizer como se os incentivos fiscais devem ser elaborados para evitar, sob o ponto de vista eleito, a violação à igualdade tributária.

\section{INCENTIVOS FISCAIS E IGUALDADE TRIBUTÁRIA}

A Constituição Federal de 1988, inovando em relação às Constituições anteriores, estabeleceu expressamente objetivos fundamentais a serem perseguidos pela República Federativa do Brasil, visando à efetivação da dignidade da pessoa humana. ${ }^{9}$ Fica claro que o Poder Constituinte originário entendeu pela necessidade de mudanças na ordem econômica e social na forma como se encontravam quando da promulgação da Constituição, preconizando, nos dizeres de Luís Eduardo Schoueri, "uma realidade social nova, ainda inexistente, cuja realização e concretização, por medidas legais, passa a ser interesse público". ${ }^{10}$ Uma Constituição com objetivos transformadores, portanto, com finalidades objetivas a serem atingidas e com um artigo $\left(3^{\circ}\right)$ que consagra aquilo que define como os objetivos fundamentais da República Federativa do Brasil.

Dentre tais objetivos fundamentais, a busca pelo desenvolvimento nacional (art. $3 .^{\circ}$, II) determina a persecução conjunta do desenvolvimento econômico e do desenvolvimento social, além do desenvolvimento humano, científico, tecnológico etc., de modo que a dissociação entre os conceitos de econômico e social, "na realidade ou no plano conceitual, pouco importa para fins de compreensão da prescrição constitucional: o desenvolvimento a

\footnotetext{
${ }^{8}$ FOLLONI, André. O papel da ciência do direito tributário no desenvolvimento nacional. In: MURTA, Antônio Carlos Diniz; BALTHAZAR, Ubaldo Cesar; FEITOSA, Raymundo Juliano Rego. (Org.). Direito Tributário. Florianópolis: Conpedi, v. 1, 2014, p. 203.

${ }^{9}$ SILVA, José Afonso da. Curso de direito constitucional positivo. 33. ed. São Paulo: Malheiros, 2010, p. 105106.

${ }^{10}$ SCHOUERI, Luís Eduardo. Normas tributárias indutoras e intervenção econômica. Rio de Janeiro: Forense, 2005 , p. 2.
} 


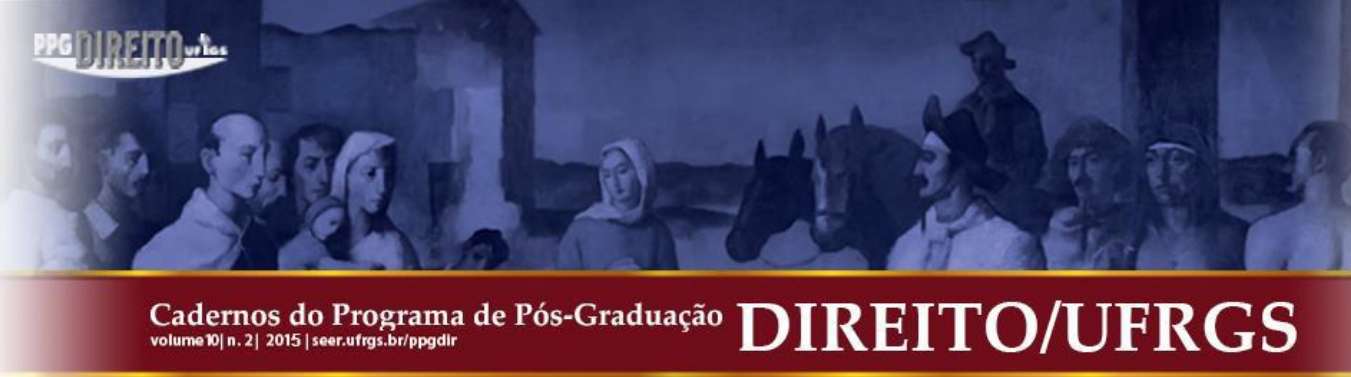

particulares, a partir de uma iniciativa do primeiro. É o que expõe Heleno Taveira Torres, ao afirmar que "a disponibilidade do incentivo fiscal decorre de uma decisão de política pública conforme a Constituição, seguida de oferta pública aos interessados da iniciativa privada para que, juntos, Estado e particulares, possam alcançar o objetivo público almejado". ${ }^{15}$

Como é natural, a concessão de incentivos fiscais, no modelo de Estado federal adotado pela Constituição, pelo qual houve a distribuição de competências materiais e tributárias entre os entes federados, envolve a competência desses entes para instituírem tributos e, com isso, aumentarem ou diminuírem a carga tributária relativa aos tributos de sua competência - eventualmente dentro de limites previstos na própria Constituição. Consequentemente, também há a competência de todos os entes federados para a concessão de incentivos fiscais em relação aos tributos para os quais a Constituição lhes reservou competência. ${ }^{16}$

Então, incentivos fiscais são empregados para atingir objetivos compreendidos como convenientes e necessários pelo Poder Público, conferindo à tributação - e, no caso, à desoneração do tributo - função extrafiscal, isto é, utilizando os tributos para incentivar determinados comportamentos com a finalidade de serem atingidos objetivos que vão para além da arrecadação. ${ }^{17}$

Considerando-se o Direito como um sistema adaptativo complexo, que se transforma e se organiza a partir das interações entre seus inúmeros agentes e das interações entre o próprio sistema e o meio ambiente no qual inserido, e que destas interações emergem propriedades não encontradas somente nos elementos que o compõem, ${ }^{18}$ o estudo dos incentivos fiscais deve considerar esta complexidade. É dizer, devem ser analisadas as interações entre tal espécie de desoneração tributária em face de outros elementos do próprio sistema jurídico, mas também os efeitos que surgem a partir da concessão dos benefícios.

Um dos principais problemas, precisamente o objeto de análise deste trabalho, diz respeito ao conflito entre os incentivos fiscais e igualdade tributária. Isso porque, como destaca Enrico de Mita, incentivar condutas nem sempre pode ser feito com atenção direta ao

\footnotetext{
${ }^{15}$ TORRES, Heleno Taveira. Segurança jurídica dos benefícios fiscais. Revista Fórum de Direito Financeiro e Econômico-RFDFE, Belo Horizonte, ano 1, n. 1, mar./ago. 2012, p. 02.

${ }^{16}$ CARRAZZA, Roque Antonio. Curso de direito constitucional tributário. 28. ed., rev. ampl. e atual. São Paulo: Malheiros, 2012, p. 569.

17 MARINS, James; TEODOROVICZ, Jeferson. Extrafiscalidade socioambiental. Revista tributária e de finanças públicas, São Paulo, v. 90, jan./fev. 2010, p. 76; OLIVEIRA, Regis Fernandes de. Taxas de polícia. São Paulo: Revista dos Tribunais, 2004, p. 68.

${ }^{18}$ FOLLONI, André. Reflexões sobre complexity science no Direito Tributário, op. cit., p. 31.
} 


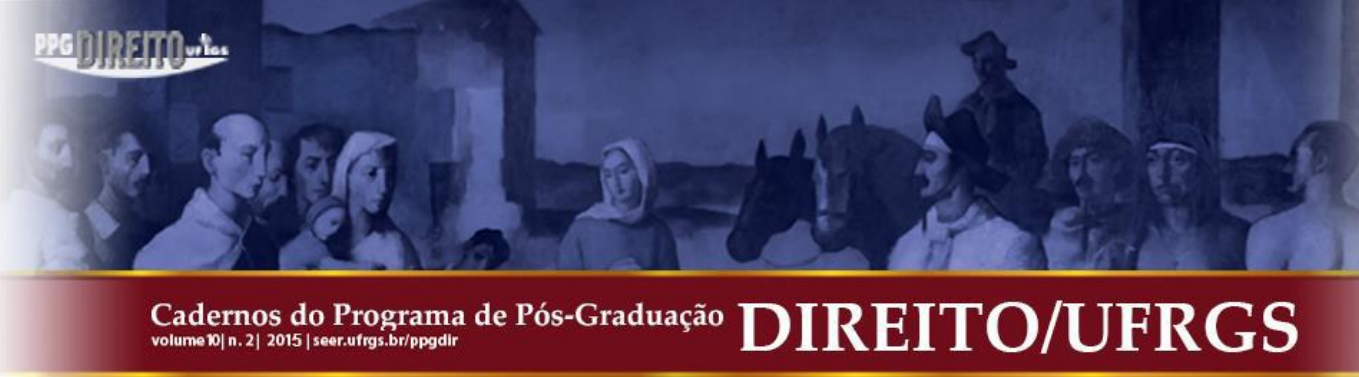

princípio da capacidade contributiva. ${ }^{19}$ É frequente a concessão de benefícios para um setor específico da atividade industrial, criando uma diferenciação entre os contribuintes em razão das atividades desempenhadas e não, propriamente, da capacidade econômica apresentada por cada contribuinte de pagar os seus tributos. Como exemplo, um benefício concedido para sociedades empresárias fabricantes de materiais de construção, e não para fabricantes de produtos de limpeza ou de eletroeletrônicos, gera uma distinção entre contribuintes que não se funda diretamente na capacidade contributiva.

Qualquer incentivo fiscal separa os contribuintes em dois grupos: de um lado os seus destinatários, aqueles contribuintes que preenchem os requisitos para a fruição do incentivo e, de outro, aqueles que não preenchem tais condições e, assim, não serão destinatários do benefício:

\begin{abstract}
A tributação extrafiscal secciona os contribuintes em dois grupos. Num primeiro grupo, inclui aqueles que são os seus destinatários, e que serão por ela atingidos, porque adotam - ou não adotam - os comportamentos que a tributação extrafiscal quer coibir - ou estimular. No segundo grupo, inclui aqueles que não são os seus destinatários, porque já adotam o comportamento desejado. Do grupo dos destinatários, os não destinatários estão excluídos, e vice-versa. ${ }^{20}$
\end{abstract}

Mesmo considerando-se os contribuintes enquadrados no mesmo grupo dos destinatários, é possível que os requisitos para a fruição do incentivo fiscal acabem por conflitar com a igualdade tributária. Imagine-se, por exemplo, que as sociedades empresárias fabricantes de materiais de construção apenas possam usufruir de um incentivo fiscal se vierem a investir um valor mínimo elevado para construção de uma planta industrial. Em princípio, o incentivo será estendido a todas as sociedades empresárias que realizem tal atividade; porém, cria uma distinção na prática, pois será restrito àquelas que possuam recursos financeiros para arcar com o ônus implicado no incentivo. Além disso, os incentivos fiscais pode também desencadear efeitos que conflitem com outros dispositivos do ordenamento jurídico, como a redução dos preços dos produtos fabricados pelos contribuintes beneficiados em relação aos demais, em possível oposição ao princípio da livre concorrência previsto no artigo 170, IV, da Constituição.

\footnotetext{
${ }^{19}$ MITA, Enrico de. O princípio da capacidade contributiva. In: FERRAZ, Roberto Catalano Botelho (Coord.). Princípios e limites da tributação. São Paulo, Quartier Latin, 2005, p. 248.

${ }^{20}$ FOLLONI, André. Isonomia na tributação extrafiscal. Revista Direito GV, São Paulo, v. 10, jan./jun. 2014, p. 208.
} 


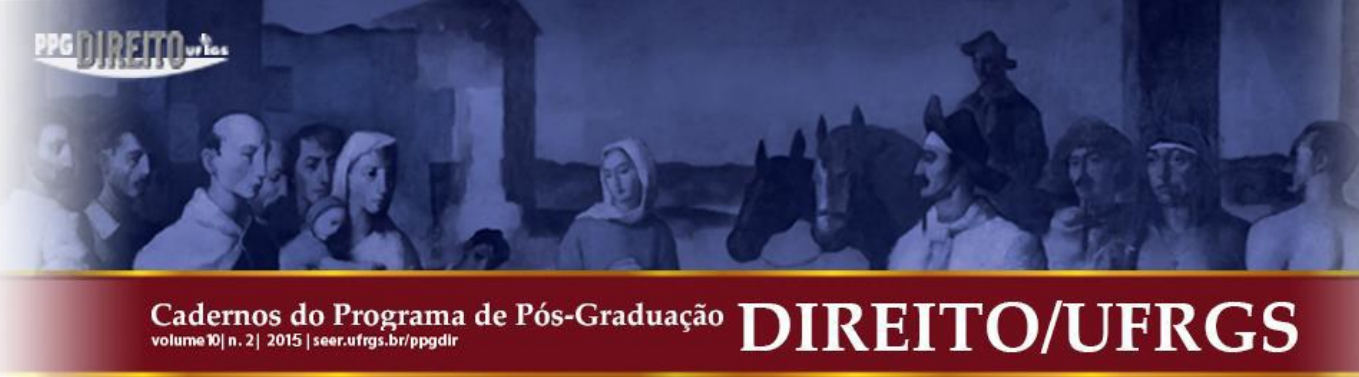

Ademais, há casos em que um benefício fiscal é concedido para determinado setor, mas criando tratamento diferenciado em razão das formas pelas quais os contribuintes desenvolvem suas respectivas atividades. Por exemplo, visando o estímulo ao trabalho, o artigo $8 .^{\circ}, \S 3 .^{\circ}$, XII, da Lei n. $12.546 / 2011$, com redação alterada pela Lei n. 12.844/2013, prevê que as sociedades empresárias que comercializem materiais de construção, no comércio varejista desse tipo de material, devem recolher a contribuição previdenciária patronal sobre a receita bruta, em substituição ao recolhimento ordinário sobre a folha de pagamento. Contudo, o inciso I, do $\S 11$, da mesma lei, determina que as empresas que desenvolvam suas atividades fora de lojas físicas, como o comércio eletrônico ou venda por call centers, recolham a contribuição sobre a folha de pagamento, ainda que exerçam, exatamente, comércio varejista de materiais de construção.

Sobre outro ponto de vista, os incentivos fiscais estão também intimamente relacionados ao orçamento do Poder Público, à medida que, classificados como renúncia de receita pelo ente concedente, à primeira vista implicam diminuição de receitas. ${ }^{21}$ Portanto, inicialmente, há necessidade de avaliação pelo ente político a respeito da intensidade de sua arrecadação e de suas receitas não tributárias, para que possa abrir mão de parcela de suas receitas para a consecução de outros objetivos - objetivos esses que, aliás, poderão eventualmente produzir maior arrecadação no futuro. ${ }^{22}$ Elegendo a segunda opção, o ente federado é obrigado a manter "as metas de resultados fiscais previstas no anexo próprio da lei de diretrizes orçamentárias" e, caso não seja possível, deve adotar "medidas de compensação (...), por meio do aumento de receita, proveniente da elevação de alíquotas, ampliação da base de cálculo, majoração ou criação de tributo ou contribuição", como determinam os incisos I e II do artigo 14 da Lei Complementar n. 101/2000, a Lei de Responsabilidade Fiscal. Depreende-se desses dispositivos que, se não for possível a manutenção das metas de resultados fiscais, a concessão do incentivo fiscal pode ocasionar o aumento de tributos para outros contribuintes, em nova relação conturbada desses incentivos com o princípio da

\footnotetext{
${ }^{21}$ PIRES, Adilson Rodrigues. Ligeiras reflexões sobre a questão dos incentivos físcais no Brasil. In: MARTINS, Ives Gandra da Silva; ELALI, André; PEIXOTO, Marcelo Magalhães (Coord.). Incentivos fiscais: questões pontuais nas esferas federal, estadual e municipal. São Paulo: MP Ed., 2007, p. 20-24.

22 SCAFF, Fernando Facury. República, tributação, finanças. Revista do Instituto de Hermenêutica Jurídica RIHJ, Belo Horizonte, ano 1, n. 6, jan./dez. 2008, p. 90-92.
} 


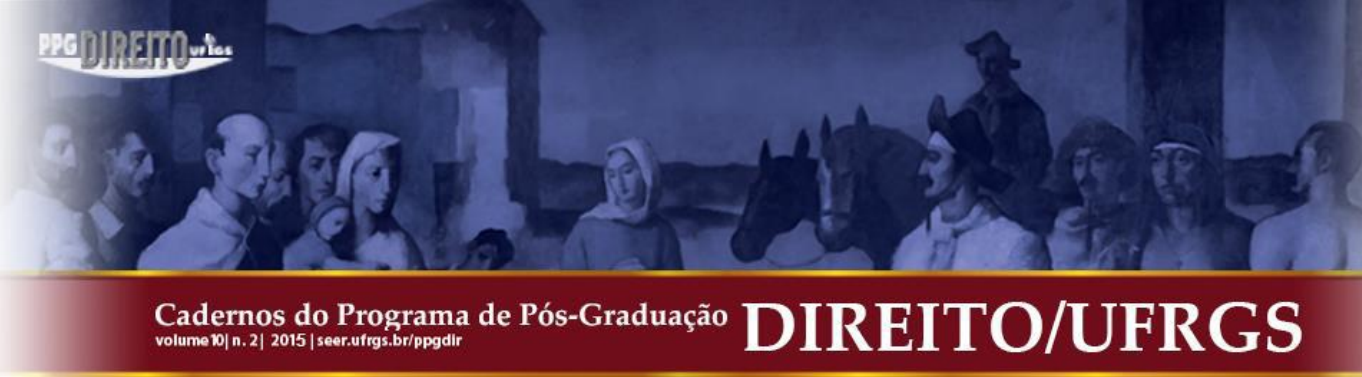

igualdade: determinadas pessoas, físicas ou jurídicas, podem ter seus tributos majorados para que outras sejam contempladas com a redução da carga tributária de outras. ${ }^{23}$

É certo que a concessão de incentivos fiscais é um juízo político concernente, primeiramente, ao Poder Legislativo, o qual detém legitimidade democrática e competência constitucional para desempenhar essa função, sob iniciativa do Poder Executivo. Porém, é necessário que os benefícios sejam utilizados com temperamentos, uma vez que, conforme demonstrado, eles acabam por restringir o princípio da igualdade tributária em diversos aspectos: pela distinção entre contribuintes destinatários beneficiados, de um lado, e contribuintes que não terão sua carga tributária reduzida, de outro; pelos requisitos impostos para a fruição do incentivo, que podem ser de alcance possível apenas por um grupo de contribuintes, e não por outro; ou, ainda, pela diferenciação dos contribuintes a partir da forma pela qual exercem suas atividades, não necessariamente fundada na capacidade contributiva; no aumento de carga tributária para aqueles contribuintes não beneficiados, no esforço de equilibrar as receitas públicas diante do défice que o incentivo fiscal, em princípio, representa; e assim por diante.

\section{INCENTIVOS FISCAIS, DIREITOS FUNDAMENTAIS E PROPORCIONALIDADE}

A realização do objetivo constitucional de desenvolvimento nacional envolve tanto o desenvolvimento econômico quanto o desenvolvimento social - além do desenvolvimento humano, científico, tecnológico, cultural etc. Uma das maneiras de se aproximar do referido objetivo é pela promoção dos direitos fundamentais. E a efetivação dos aludidos direitos fundamentais possui estreita relação com a tributação, porquanto esta fornece os recursos necessários para que o Estado trabalhe para os assegurar, de um lado, e porque permite, por meio da função extrafiscal, o estímulo de condutas adequadas para a promoção desses direitos e o desestímulo dos comportamentos inadequados. ${ }^{24}$

Os direitos fundamentais encontram base contemporânea na dignidade da pessoa humana, fundamento do Estado Democrático de Direito brasileiro, e são considerados direitos

\footnotetext{
${ }^{23}$ SANCHES, José Luis Saldanha. Manual de direito fiscal. Lisboa: 1998, p. 33.

${ }^{24}$ CALIENDO, Paulo. Direito tributário: três modos de pensar a tributação: elementos para uma teoria sistemática do direito tributário. Porto Alegre: Livraria do Advogado Editora, 2009, p. 25; GOUVÊA, Marcus de Freitas. Questões relevantes acerca da extrafiscalidade no Direito Tributário. Interesse Público - IP, Belo Horizonte, n. 34, nov./dez. 2005, p. 180.
} 


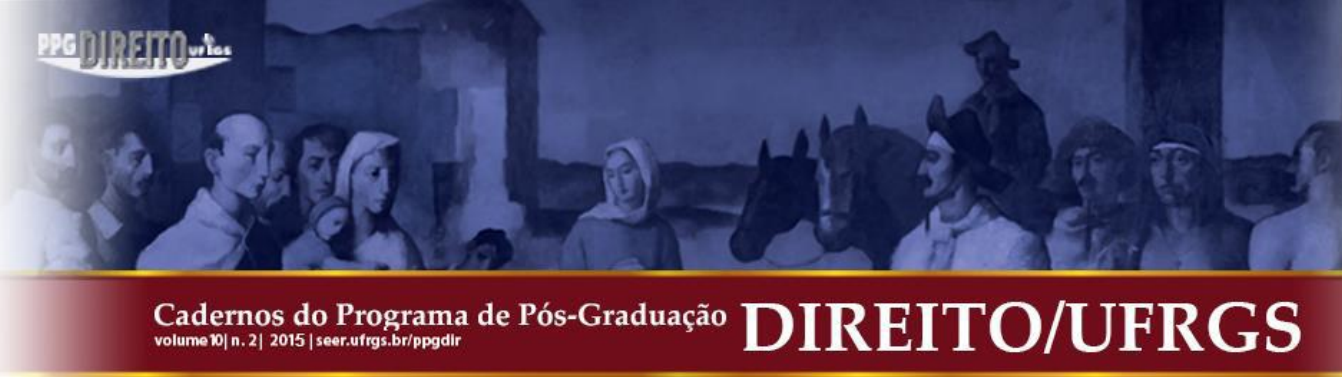

indispensáveis para que as pessoas gozem de existência livre, igual e digna. ${ }^{25}$ No ordenamento jurídico brasileiro, a Constituição consagra uma série de direitos fundamentais, desde os direitos de primeira dimensão, individuais, como direito à vida e à igualdade (art. $5^{\circ}$, caput), o direito à liberdade de crença (art. 5\%, VI), o direito à liberdade de expressão e manifestação de pensamento (art. $5^{\circ}$, IX) e o direito de propriedade (art. $5^{\circ}$, caput e XXII), até os direitos de segunda dimensão, sociais, como o direito à educação e à saúde ( $\left.\operatorname{art.} 6^{\circ}\right)$, além dos direitos coletivos e difusos. Tais direitos são previstos, principalmente, no Título II da CF, que identifica os "Direitos e Garantias Fundamentais", mas tal rol não é taxativo, pois o próprio texto constitucional prevê a possibilidade de reconhecimento de outros direitos fundamentais decorrentes de normas situadas em outros títulos da Constituição (art. $5 .^{\circ}, \S$ 2. ${ }^{\circ}$ ), além da possibilidade de ampliação do conteúdo desses direitos pela edição de normas infraconstitucionais, de modo que as normas legais passam a integrar o conteúdo dos direitos fundamentais. $^{26}$

Esses direitos recebem um regime especial de proteção constitucional. Conforme se depreende do artigo $5 .^{\circ}, \S 1 .^{\circ}$, da Constituição, "as normas definidoras de direitos e garantias fundamentais têm aplicação imediata”. Gozam, também, do status de cláusulas pétreas, nos termos do artigo 60, $\S 4 .^{\circ}, \mathrm{IV}$, do texto constitucional, de modo que, pela sua importância, são protegidos contra abolições não só pelas maiorias parlamentares simples e absoluta como, também, pelo Poder Constituinte derivado.

Conforme Robert Alexy, um “direito fundamental completo é um feixe de posições de direitos fundamentais". ${ }^{27}$ Isto significa que, de um mesmo direito fundamental, decorrem posições jurídicas diversas e que impõe distintos deveres ao Poder Público. Em face dessa diversidade de posições, são atribuídas múltiplas funções aos direitos fundamentais, as quais podem ser classificadas, teoricamente, em dois grupos: funções de defesa e funções de prestação.

\footnotetext{
${ }^{25}$ SILVA, De Plácido e. Vocabulário Jurídico. Atualizado por Nagib Salibi Filho e Priscila Pereira Vasques Gomes. 31. ed. Rio de Janeiro: Forense, 2014, p. 743.

${ }^{26}$ HACHEM, Daniel Wunder. Tutela administrativa efetiva dos direitos fundamentais sociais: por uma implementação espontânea, integral e igualitária. Curitiba, 2014. 614 f. Tese (Doutorado em Direito) - Programa de Pós-Graduação em Direito, Universidade Federal do Paraná, p. 142-144; NOVAIS, Jorge Reis. Direitos sociais: teoria jurídica dos direitos sociais enquanto direitos fundamentais. Coimbra: Coimbra Editora, $2010, \mathrm{p}$. 155-179.

${ }^{27}$ ALEXY, Robert. Teoria dos direitos fundamentais. Tradução de Virgílio Afonso da Silva. 2. ed., 3. tir. São Paulo: Malheiros, 2014, p. 249.
} 


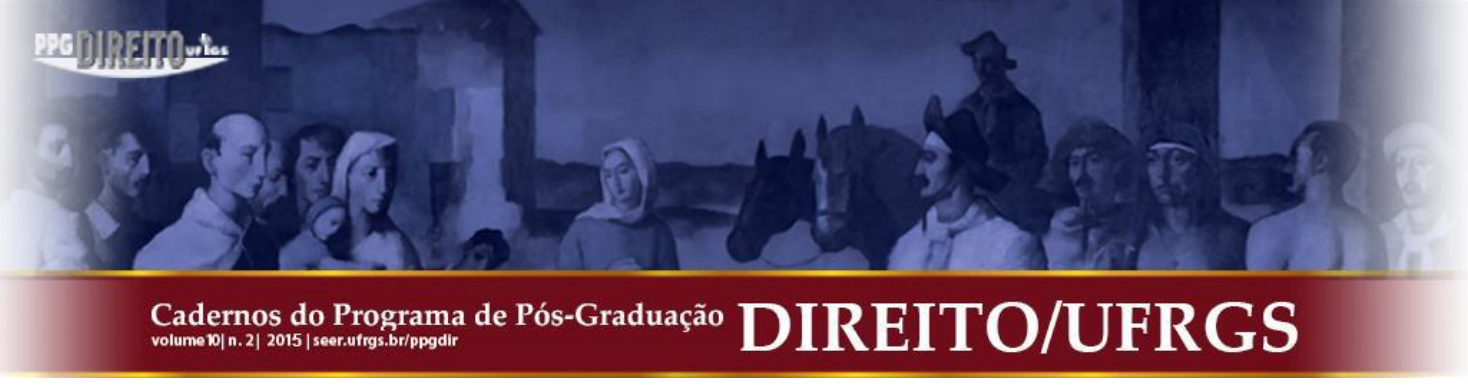

A função de defesa impõe deveres negativos ao Estado, a fim de que este não intervenha nas ações do titular do direito. ${ }^{28}$ Naturalmente, esse termo "deveres negativos" não deve admitir conotação relativa a total abstenção estatal, uma vez que os direitos individuais necessitam de ação comissiva estatal para sua proteção, muitas vezes intensa e custosa. Tratase, contudo, de direitos mais relacionados à proteção do que de promoção.

Já a função prestacional propriamente dita atribui ao Estado os deveres de promoção dos direitos fundamentais, isto é, de construir aquilo que ainda não existe na realidade social. Assim, deve fornecer as prestações materiais necessárias à promoção dos direitos, além de impedir a intervenção de particulares em direitos fundamentais de outros indivíduos e criar procedimentos que viabilizem o acesso àqueles direitos. Nesse sentido, aduz Daniel Wunder Hachem:

\begin{abstract}
A faceta prestacional dos direitos fundamentais revela-se nas posições jurídicas que impõem ao Estado a persecução de determinados objetivos, exigindo-se a criação dos pressupostos fáticos e jurídicos necessários para o exercício dos direitos. O aspecto prestacional pode se apresentar de variadas formas, conforme a natureza da prestação exigida pela norma de direito fundamental. Poderão ser prestações em sentido estrito (também chamadas de materiais ou fáticas), englobando as pretensões jurídicas do indivíduo frente ao Estado a algo que, se ele possuísse meios financeiros suficientes e se encontrasse no mercado uma oferta satisfatória, poderia obter também dos particulares (...). As ações positivas exigidas pela função de prestação poderão, por outro lado, constituir prestações no sentido amplo, também compreendidas como prestações normativas. São os direitos à elaboração de normas pelo Poder Público, seja pelo Legislativo, seja pelo Executivo, necessárias à proteção de determinados bens jurídicos (função de proteção) ou à criação de organizações e procedimentos que auxiliem na promoção e na proteção dos direitos fundamentais (função de organização e de procedimento). ${ }^{29}$
\end{abstract}

Considerando-se que a Constituição tratou dos direitos fundamentais de forma bastante minuciosa, e em razão da multifuncionalidade destes direitos, para que o Poder Público cumpra seus deveres e tanto os proteja quanto os promova, mormente no tocante ao aspecto prestacional, necessita de um volume considerável de recursos financeiros. Isso porque, em última análise, a função prestacional implicará despesas para criação das condições necessárias com a finalidade de assegurar os direito fundamentais, seja pela implementação de procedimentos ou organizações - prestações de organização e procedimento - seja pela garantia de acesso dos indivíduos a serviços já existentes -

\footnotetext{
${ }^{28}$ Ibidem, p. 196.

${ }^{29}$ HACHEM, Daniel Wunder. op. cit., p. 131. Este também é o posicionamento de NOVAIS, Jorge Reis. op. cit., p. 257-269.
}

Cadernos do Programa de Pós-Graduação em Direito PPGDir./UFRGS | Edição Digital | Porto Alegre | Volume X | Número 2 | 2015 | P. 341 - 363 


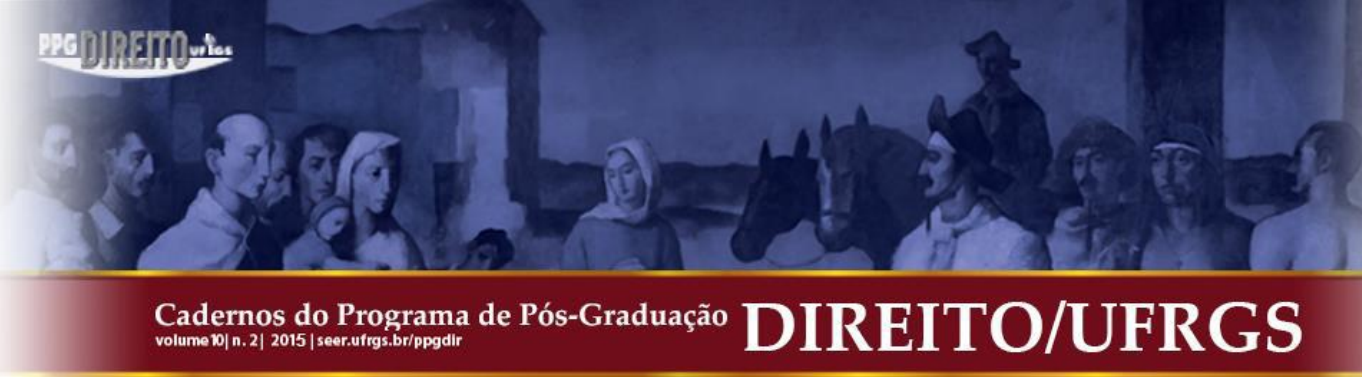

prestações fáticas. ${ }^{30}$ Nesse contexto, a tributação, pela via da obtenção de receitas públicas, serve como mecanismo que viabiliza a realização de despesas públicas e, com isso, a promoção dos direitos fundamentais.

Contudo, essa promoção pode ser dificultada diante da insuficiência de recursos financeiros públicos, obstando a exequibilidade de que o Estado forneça as prestações necessárias para assegurar aquele amplo rol de direitos fundamentais. Em tais hipóteses, a escassez de recursos impede a realização de todos os direitos fundamentais, cabendo ao Poder Público eleger a alocação dos mencionados recursos diante de múltiplas possibilidades de escolha. $^{31}$

A Constituição prescreveu como objetivo fundamental a busca pelo desenvolvimento nacional e tal busca apenas se viabiliza com a promoção dos direitos fundamentais. Desse modo, a concessão de incentivos fiscais pode ser utilizada como instrumento que viabilize a concretização dessa espécie de direitos e, consequentemente, proporcionem o desenvolvimento nacional, desde que precedida de estudos que garantam o equilíbrio no orçamento público. ${ }^{32}$

Se as normas que instituem incentivos fiscais pretendem encorajar comportamentos que, em princípio, não seriam realizados, ou o seriam insuficientemente, visando em última instância à promoção de direitos fundamentais, é possível justificar a utilização desses benefícios, à medida que sejam empregados como meio para se atingir fins constitucionalmente estipulados, admitindo-se, até mesmo, em alguns casos, a restrição de outros direitos fundamentais, como a igualdade.

Contudo, nesses caso, como fica claro, da lei que concede o incentivo fiscal emerge uma colisão entre direitos fundamentais previstos na Constituição: de um lado, tem como alicerce um direito fundamental; de outro, conflita com a igualdade, também um direito fundamental.

\footnotetext{
${ }^{30}$ NOVAIS, Jorge Reis. op. cit., p. 89-91.

${ }^{31}$ CALIENDO, Paulo. A extrafiscalidade como instrumento de implementação dos direitos fundamentais sociais no Brasil. Revista Jurídica do Cesuca, Cachoeirinha-RS, v. 2, n. 4, dez. 2014, p. 62-63.

32 Sobre a possibilidade de utilização da finalidade extrafiscal da tributação para promoção de direitos fundamentais: CALIENDO, Paulo. A Extrafiscalidade como instrumento de implementação dos direitos fundamentais sociais no Brasil, op. cit.; FOLLONI, André; PERON, Rita de Cássia Andrioli Bazila. Tributação extrafiscal e direitos fundamentais: Programa Empresa Cidadã e licença maternidade. Revista Espaço Jurídico, Chapecó, v. 15, jul./dez. 2014, p. 399-420; BUFFON, Marciano. A tributação como instrumento de concretização dos direitos fundamentais. Revista da Faculdade de Direito - UFU, Uberlândia, v. 38, n. 2, jul./dez. 2010, p. 555-579,.
} 


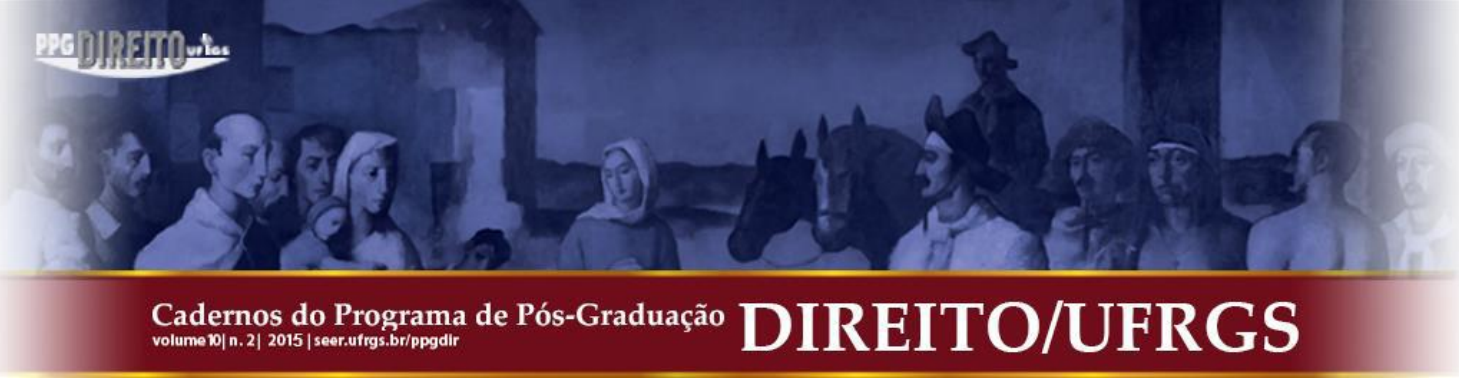

Em vista disso, há a necessidade de se verificar, sob esse ponto de vista, da restrição ao direito fundamental de igualdade, a validade da referida lei, ponderando-se qual direito fundamental deve prevalecer. Tal avaliação passa pelo exame da proporcionalidade, a qual “incide como metanorma, a estruturar o modo de aplicação, sobre aquela lei, tanto dos princípios que prescrevem os fins visados pela tributação extrafiscal, quanto das normas que prescrevem os direitos por ela restringidos". 33

A análise da proporcionalidade pressupõe a existência de uma relação entre um meio para realização de uma finalidade e a própria finalidade a ser realizada, devendo-se averiguar se o referido meio é, em primeiro lugar, adequado para atingir o fim almejado; em segundo lugar, se existem outros meios que limitem menos os direitos envolvidos; e, por fim, se o objetivo a ser alcançado justifica a restrição a outros direitos. Ou seja, deve-se verificar a adequação, a necessidade e a proporcionalidade em sentido estrito desta relação entre meio e fim. É importante recorrer, aqui, à lição de Humberto Ávila:

O exame de proporcionalidade aplica-se sempre que houver uma medida concreta destinada a realizar uma finalidade. Nesse caso devem ser analisadas as possibilidades de a medida levar à realização da finalidade (exame da adequação), de a medida ser a menos restritiva aos direitos envolvidos dentre aquelas que poderiam ter sido utilizadas para atingir a finalidade (exame da necessidade) e da finalidade pública ser tão valorosa que justifique tamanha restrição (exame da proporcionalidade em sentido estrito).

Em sentido semelhante é o entendimento de Juan José Moreso:

El principio de proporcionalidad... comprende tres subprincipios: a) el principio adecuación, es decir, que el sacrificio impuesto en el ejercicio de un derecho sea adecuado para preservar otro derecho o un bien constitucionalmente protegido, b) el principio de necesidad, esto es, que el sacrificio impuesto sea necesario -que no exista otro menos lesivo- para preservar otro derecho o un bien constitucionalmente protegido, y c) el principio de proporcionalidad en sentido estricto, en donde la ponderación propiamente dicha ocupa su lugar, formulada en la denominada ley del balance: "cuanto mayor sea el grado de la no satisfacción o de afectación de uno de los principios, tanto mayor debe ser la importancia de la satisfacción del otro. ${ }^{35}$

\footnotetext{
${ }^{33}$ FOLLONI, André. Isonomia na tributação extrafiscal, op. cit., p. 212.

34 ÁVILA, Humberto. Teoria dos princípios: da definição à aplicação dos princípios jurídicos. 12. ed., ampl. São Paulo: Malheiros, 2011, p. 174-175.

${ }^{35}$ MORESO, José Juan. Alexy y la aritmética de la ponderación. In: GARCÍA MANRIQUE, Ricardo. Derechos sociales y ponderación. Madrid: Fundación Colóqui Jurídico Europeo, 2007, p. 226-227.
} 


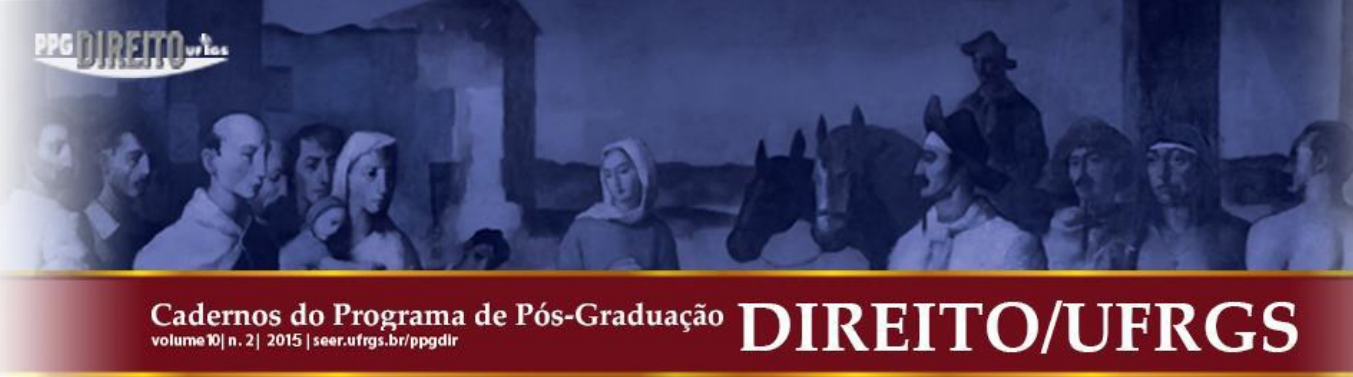

Desse modo, em um primeiro momento, a medida adotada deve ser compatível com o fim almejado, isto é, ela deve ser adequada para a promoção da finalidade. Para esse exame preliminar, é irrelevante que o objetivo possa ser realizado por outros meios, porque, se o meio eleito não for factível, sua invalidade ficará, desde logo, caracterizada. Por essa razão, trata-se de um critério negativo, porquanto a adequação visa somente verificar se a medida é adequada para a realização da finalidade pretendida, e não se ela é a mais apropriada. ${ }^{36}$ Assim, se o incentivo fiscal for um instrumento capaz de efetivar o direito fundamental, será adequado, não importando, por enquanto, se existem outros meios para melhor concretização do referido direito. Veja-se, por exemplo, a concessão de um benefício fiscal às empresas que desenvolvem a atividade de transporte ambulatorial. Se tal desoneração resultar na diminuição dos custos do transporte ambulatorial e, com isso, indivíduos mais carentes puderem ter acesso a esse serviço, ampliando-se o acesso ao direito fundamental à saúde, o incentivo fiscal será adequado.

Isso, contudo, não significa sua validade, sob o ponto de vista da proporcionalidade. Passando pelo crivo da adequação, deve-se verificar, ainda, a necessidade da medida adotada. Essa necessidade é definida por Robert Alexy como o "mandamento do meio menos gravoso". ${ }^{37}$ Se no exame da adequação basta a demonstração de que a medida utilizada é apta a alcançar o objetivo, nesse segundo momento compara-se aquela medida com outros meios também capazes de realizar o mesmo fim, buscando-se verificar qual deles restringe com menor intensidade o direito fundamental abalado.

O exame da necessidade é composto por duas etapas: (i) deve ser perquirida a existência de outros meios para a realização da finalidade pretendida; (ii) existindo outros meios, investiga-se qual deles restringe "em menor medida os direitos fundamentais colateralmente afetados". ${ }^{38}$ No exemplo acima, o acesso ao transporte ambulatorial e, consequentemente, ao direito fundamental à saúde, pode ser ampliado tanto pela concessão de incentivo fiscal aos prestadores daquele serviço, como, por exemplo, pelo fornecimento desse serviço diretamente pelo Poder Público. Por isso, ao optar pela primeira medida, o Poder Público deve "demonstrar que verificou meios alternativos e concluiu serem esses meios,

\footnotetext{
${ }^{36}$ ALEXY, Robert. Teoria dos direitos fundamentais, op. cit., p. 590; ÁVILA, Humberto. Teoria dos princípios, op. cit., p. 178; FOLLONI, André. Isonomia na tributação extrafiscal, op. cit., p. 214.

${ }^{37}$ ALEXY, Robert. Teoria dos direitos fundamentais, op. cit., p. 116-117.

${ }^{38}$ ÁVILA, Humberto. Teoria dos princípios, op. cit., p. 182.
} 


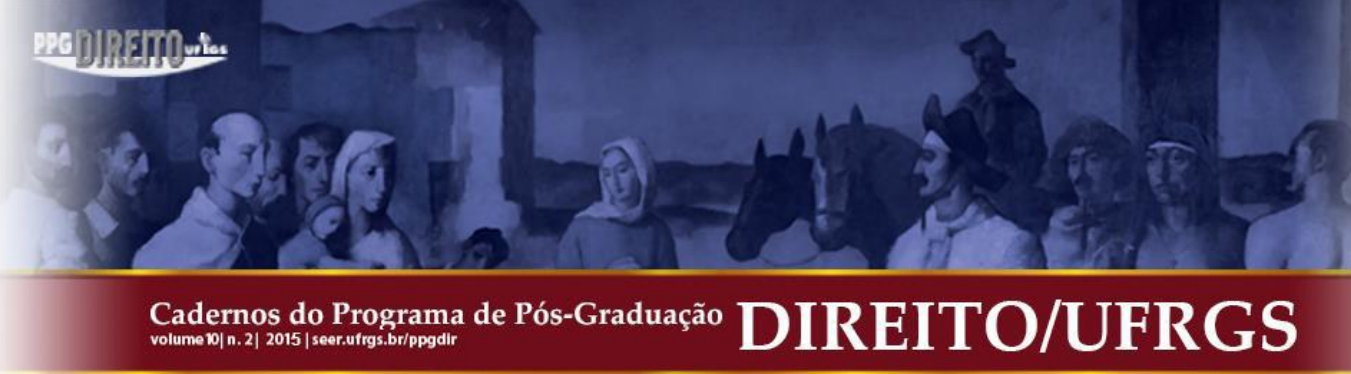

razoavelmente equivalentes no que concerne à promoção da finalidade, mais restritivos a outros direitos". 39

Constatando-se a adequação e a necessidade do meio em face do fim constitucional prescrito, passa-se à terceira e última fase do exame da proporcionalidade, conhecida como proporcionalidade em sentido estrito. É nessa etapa final que ocorre o sopesamento entre os direitos fundamentais colidentes, comparando-se o grau de importância entre a restrição de um direito em face da realização de outro.

A averiguação da proporcionalidade em sentido estrito divide-se em três estágios, na visão de Robert Alexy: (i) em primeiro lugar, considera-se o grau da restrição de um direito, classificando tal restrição em leve, moderada ou séria; (ii) em segundo lugar, verifica-se a importância da satisfação do direito a ser promovido, a partir das razões que sustentam tal objetivo, classificando as razões em fracas, moderadas ou fortes $;^{40}$ (iii) por fim, ponderam-se os resultados obtidos pelas classificações anteriores, de modo que restrições leves ou moderadas são possíveis em face de razões fortes, enquanto não se justifica uma séria restrição a um direito fundamental por uma razão fraca ou moderada. Já nas hipóteses de equivalência entre os níveis das razões e restrições - isto é, razões fortes e restrições sérias; razões moderadas e restrições moderadas; e razões fracas e restrições leves - "el legislador goza de discreción para afectar uno u otro derecho, lo que equivale a decir que, en los casos de empate, las restricciones legislativas al ejercicio de un derecho fundamental están justificadas". 41

Assim, em síntese, à medida que a Constituição prescreve a busca pelo desenvolvimento nacional como objetivo, e a realização dos direitos fundamentais está envolvida nesse objetivo, é possível o emprego de incentivos fiscais para promoção desses direitos. Todavia, como os benefícios fiscais conflitam com a igualdade tributária, ao menos potencialmente, sua utilização deve ser pautada por alguns requisitos, dentre os quais se encontra o exame da proporcionalidade.

A mera indicação de que determinado incentivo fiscal visa à promoção de um direito fundamental é insuficiente, portanto; o Poder Público deve demonstrar e justificar, de forma

\footnotetext{
${ }^{39}$ FOLLONI, André. Isonomia na tributação extrafiscal, op. cit., p. 215.

${ }^{40}$ ALEXY, Robert. Teoria dos direitos fundamentais, op. cit., p. 593; ALEXY, Robert. Constitutional rights, balancing, and rationality. Ratio Juris, Oxford, v. 16, n. 2, jun. 2002, p. 136; FOLLONI, André. Isonomia na tributação extrafiscal, op. cit., p. 216; MORESO, José Juan. op. cit., p. 227.

${ }^{41}$ MORESO, José Juan. op. cit., p. 228.
} 


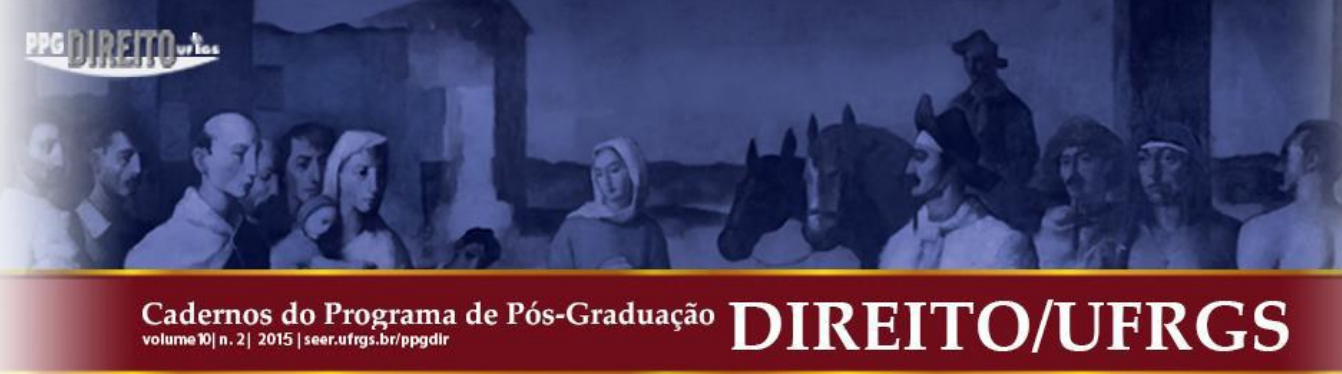

expressa, sua adequação, necessidade e proporcionalidade em sentido estrito. ${ }^{42}$ Satisfeitas essas exigências, será justificável, sob esse ponto de vista, a concessão do incentivo fiscal, ainda que com restrições à igualdade.

\section{CONSIDERAÇÕES FINAIS}

O Estado brasileiro, enquanto Estado Democrático de Direito, deve promover os direitos fundamentais e, enquanto ator decisivo para a República, deve buscar a garantia do desenvolvimento nacional. A Constituição, além de prescrever um amplo rol de direitos fundamentais, conferiu a esses direitos um regime de proteção especial, dotando-os de aplicabilidade imediata e também vedando a sua abolição do ordenamento jurídico brasileiro, à medida que os qualificou como cláusulas pétreas. Tais direitos são também dotados de multifuncionalidade, impondo ao Estado tanto o dever de respeito, na função de proteção, quanto o dever de prestação, na função de promoção. Não bastasse tal importância intrínseca dos direitos fundamentais, a promoção deles contribui para a realização do objetivo fundamental de desenvolvimento nacional, previsto no artigo $3 .^{\circ}$, II, da Constituição.

Contudo, em face dos múltiplos direitos a serem protegidos e promovidos, existem situações em que, por motivos variados, não é possível ou conveniente que o Estado forneça todas as prestações necessárias para a garantia de todos os direitos fundamentais.

Nestes casos, uma alternativa ao Poder Público é a utilização de incentivos fiscais como instrumentos para estimular a colaboração dos particulares na promoção e realização dos direitos fundamentais. Contudo, para além dessa justificativa, necessária mas não suficiente, a validade dos incentivos fiscais deve observar outros requisitos, principalmente pelo fato de que estes benefícios geram distinções e, assim, conflitam com a igualdade tributária.

Esse artigo defende que um desses requisitos é o exame da proporcionalidade. Então, se um incentivo fiscal tiver como finalidade a concretização de um direito fundamental e, dentre outros requisitos, demonstrar-se adequado, necessário e proporcional, ele será, sob esse ponto de vista, válido.

\footnotetext{
${ }^{42}$ FOLLONI, André. Isonomia na tributação extrafiscal, op. cit., p. 217.
} 


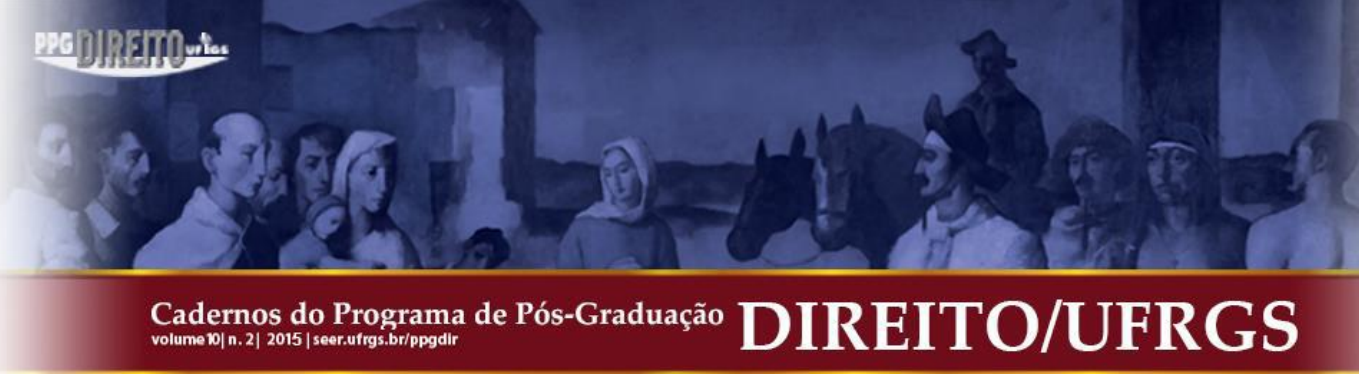

\section{REFERÊNCIAS}

ALEXY, Robert. Constitutional rights, balancing, and rationality. Ratio Juris, Oxford, v. 16, n. 2, jun. 2002, p. 131-140.

. Teoria dos direitos fundamentais. Tradução de Virgílio Afonso da Silva. 2. ed., 3. tir. São Paulo: Malheiros, 2014.

ARTHUR, W. Brian. The end of certainty in economics. In: AERTS, Diederik; BROEKAERT, Jan; MATHIJS, Ernest (Eds.). Einstein meets Magritte: an interdisciplinary reflection on science, nature, art, human action and society. v. 1. Amsterdam: Springer, 1999.

ÁVILA, Humberto. A doutrina e o Direito Tributário. In: (Org.). Fundamentos do

Direito Tributário. Madri: Marcial Pons, 2012, p. 221-245.

Teoria dos princípios: da definição à aplicação dos princípios jurídicos. 12. ed., ampl. São Paulo: Malheiros, 2011.

BOBBIO, Norberto. Da estrutura à função: novos estudos de teoria do direito. Barueri-SP: Manole, 2007.

BORGES, José Souto Maior. Um ensaio interdisciplinar em Direito Tributário: superação da dogmática. Revista Dialética de Direito Tributário, São Paulo, n. 211, abr./2013, p. 106-212.

BUFFON, Marciano. A tributação como instrumento de concretização dos direitos fundamentais. Revista da Faculdade de Direito - UFU, Uberlândia, v. 38, n. 2, p. 555-579, jul./dez. 2010.

CALIENDO, Paulo. Direito tributário: três modos de pensar a tributação: elementos para uma teoria sistemática do direito tributário. Porto Alegre: Livraria do Advogado Editora, 2009.

A Extrafiscalidade como instrumento de implementação dos direitos fundamentais sociais no Brasil. Revista Jurídica do Cesuca, Cachoeirinha-RS, v. 2, n. 4, p. 62-86, dez. 2014.

CANO, Wilson. Uma agenda nacional para o desenvolvimento. Leituras de Economia Política, Campinas, n. 21, dez. 2012/jul. 2013, p. 35-73. 


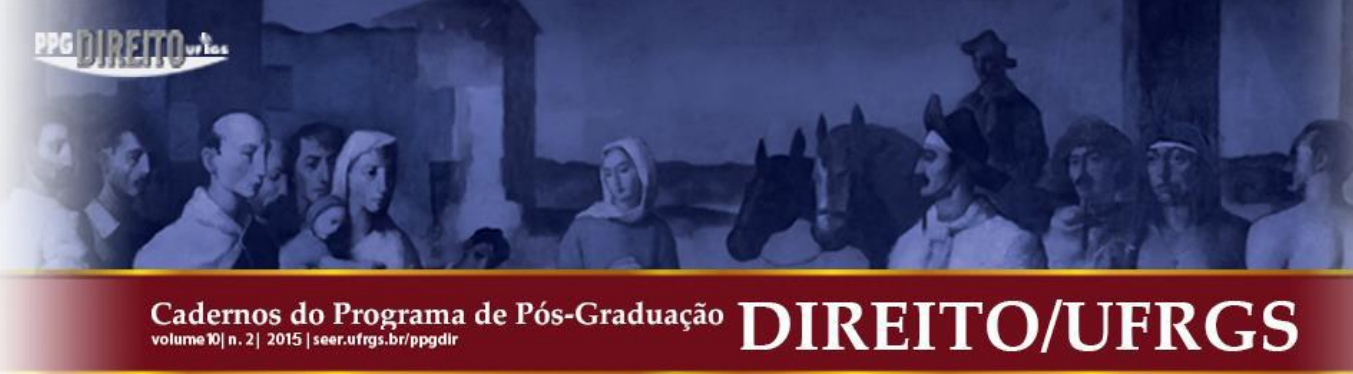

CARRAZZA, Roque Antonio. Curso de direito constitucional tributário. 28. ed., rev. ampl. e atual. São Paulo: Malheiros, 2012.

FOLLONI, André. A complexidade ideológica, jurídica e política do desenvolvimento sustentável e a necessidade de compreensão interdisciplinar do problema. Revista Mestrado em Direito (UNIFIEO. Impresso), Osasco, v. 41, 2014, p. 63-91.

Ciência do direito tributário no Brasil: crítica e perspectivas a partir de José Souto Maior Borges. São Paulo: Saraiva, 2013.

. Isonomia na tributação extrafiscal. Revista Direito GV, São Paulo, v. 10, jan./jun. 2014, p. 201-220.

O papel da ciência do direito tributário no desenvolvimento nacional. In: MURTA, Antônio Carlos Diniz; BALTHAZAR, Ubaldo Cesar; FEITOSA, Raymundo Juliano Rego. (Org.). Direito Tributário. Florianópolis: Conpedi, v. 1, 2014, p. 191-21.

Reflexões sobre complexity science no Direito Tributário. In: MACEI, Demetrius Nichele et al. (Org.). Direito tributário e filosofia. Curitiba: Instituto Memória, 2014, p. 2437.

FOLLONI, André; PERON, Rita de Cássia Andrioli Bazila. Tributação extrafiscal e direitos fundamentais: Programa Empresa Cidadã e licença maternidade. Revista Espaço Jurídico, Chapecó, v. 15, p. 399-420, jul./dez. 2014.

GOUVÊA, Marcus de Freitas. Questões relevantes acerca da extrafiscalidade no Direito Tributário. Interesse Público - IP, Belo Horizonte, n. 34, p. 175-200, nov./dez. 2005.

GRECO, Marco Aurélio. Do poder à função tributária. In: FERRAZ, Roberto. Princípios e limites da tributação 2. São Paulo: Quartier Latin, 2009, p. 167-176.

HACHEM, Daniel Wunder. Tutela administrativa efetiva dos direitos fundamentais sociais: por uma implementação espontânea, integral e igualitária. Curitiba, 2014. 614 f. Tese (Doutorado em Direito) - Programa de Pós-Graduação em Direito, Universidade Federal do Paraná. 


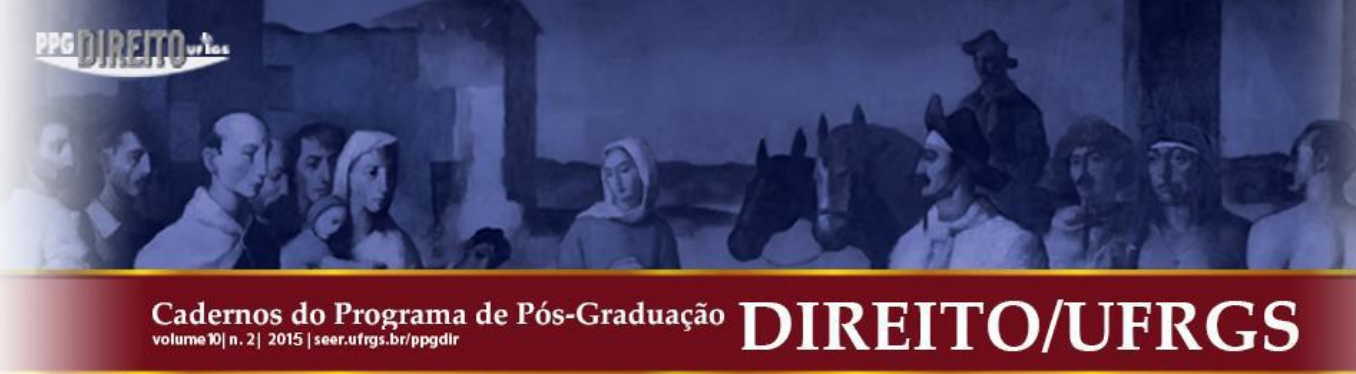

MARINS, James; TEODOROVICZ, Jeferson. Extrafiscalidade socioambiental. Revista tributária e de finanças públicas, São Paulo, v. 90, p. 73-123, jan./fev. 2010.

MITA, Enrico de. O princípio da capacidade contributiva. In: FERRAZ, Roberto Catalano Botelho (Coord.). Princípios e limites da tributação. São Paulo, Quartier Latin, 2005, p. 221256.

MORESO, José Juan. Alexy y la aritmética de la ponderación. In: GARCÍA MANRIQUE, Ricardo. Derechos sociales y ponderación. Madrid: Fundación Colóqui Jurídico Europeo, 2007, p. 223-248.

NOGUEIRA, Ruy Barbosa. Curso de direito tributário. 14. ed., atual. São Paulo: Saraiva, 1995.

NOVAIS, Jorge Reis. Direitos sociais: teoria jurídica dos direitos sociais enquanto direitos fundamentais. Coimbra: Coimbra Editora, 2010.

OLIVEIRA, Regis Fernandes de. Extrafiscalidade. Revista Fórum de Direito Financeiro e Econômico-RFDFE, Belo Horizonte, ano 3, n. 4, p. 13-30, set. 2013/fev. 2014.

Taxas de polícia. São Paulo: Revista dos Tribunais, 2004.

PIRES, Adilson Rodrigues. Ligeiras reflexões sobre a questão dos incentivos fiscais no Brasil. In: MARTINS, Ives Gandra da Silva; ELALI, André; PEIXOTO, Marcelo Magalhães (Coord.). Incentivos fiscais: questões pontuais nas esferas federal, estadual e municipal. São Paulo: MP Editora, 2007, p. 13-34.

PEREIRA, Luiz Carlos Bresser. Desenvolvimento e crise no Brasil. 7. ed., São Paulo: Brasiliense, 1977.

SANCHES, José Luis Saldanha. Manual de direito fiscal. Lisboa: 1998.

SCAFF, Fernando Facury. República, tributação, finanças. Revista do Instituto de Hermenêutica Jurídica - RIHJ, Belo Horizonte, ano 1, n. 6, p. 79-104, jan./dez. 2008. 


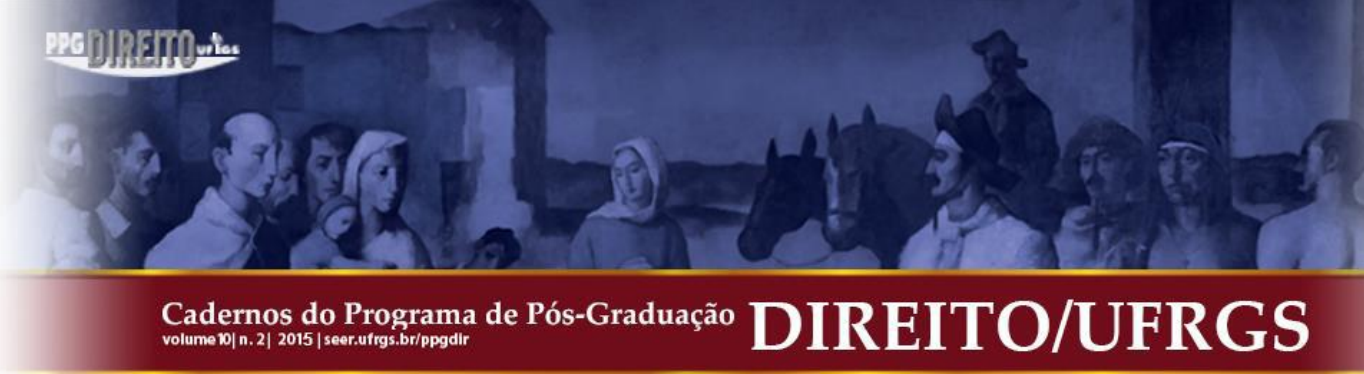

SCHOUERI, Luís Eduardo. Normas tributárias indutoras e intervenção econômica. Rio de Janeiro: Forense, 2005.

SILVA, De Plácido e. Vocabulário Jurídico. Atualizado por Nagib Salibi Filho e Priscila Pereira Vasques Gomes. 31. ed. Rio de Janeiro: Forense, 2014.

SILVA, José Afonso da. Curso de direito constitucional positivo. 33. ed. São Paulo: Malheiros, 2010.

SILVEIRA NETO, Otacílio dos Santos. A instrumentalidade da atividade financeira do Estado como indutora do desenvolvimento econômico: o papel dos incentivos fiscais na promoção da livre concorrência e da livre iniciativa. Revista de Direito Público da Economia $-R D P E$, Belo Horizonte, ano 11, n. 41, p. 119-135.

TORRES, Heleno Taveira. Segurança jurídica dos benefícios fiscais. Revista Fórum de Direito Financeiro e Econômico - RFDFE, Belo Horizonte, ano 1, n. 1, p. 57-91, mar./ago. 2012.

Submissão: 18/09/2015 Aceito para Publicação: 27/10/2015 
